\title{
Effect of diets of different protein concentrations on indigenous growing chicks of Bangladesh in confinement
}

\author{
M. Yousuf Miah ${ }^{1,3 *}$, Sachchidananda Das Chowdhury ${ }^{1}$ and A. K. Fazlul Haque Bhuiyan ${ }^{2}$ \\ ${ }^{1}$ Department of Poultry Science, Bangladesh Agricultural University, Mymensingh-2202, Bangladesh \\ ${ }^{2}$ Department of Animal Breeding and Genetics, Bangladesh Agricultural University, Mymensingh-2202, \\ Bangladesh \\ ${ }^{3}$ Present address: Department of Poultry Science, Sylhet Agricultural University, Sylhet, Bangladesh
}

*Corresponding author: Dr. M. Yousuf Miah, Department of Poultry Science, Sylhet Agricultural University, Sylhet, Bangladesh. E-mail: myoumsau2003@gmail.com

Received: 20 May 2015/Accepted: 18 June 2015/ Published: 30 June 2015

\begin{abstract}
An experiment was conducted to evaluate the effect of diets varying in protein concentrations on indigenous (desi) growing chicks reared under confinement system. The feeding trial was conducted with 144 indigenous female (desi) growing chicks during 12-22 weeks of age. The birds were divided into four dietary treatments each of three replications and reared on littered floor in an open-sided house. The number of birds in each replication was 12. Four iso-nitrogenous grower diets differing in protein contents were formulated to constitute dietary treatments. Diets for comparison were: control (a mixture of broken rice, rice polish, protein concentrate etc); low protein density (LPD): CP 15\%; moderate protein density (MPD): CP 17\% and high protein density (HPD): CP 19\%. Metabolizable energy was maintained $2700 \mathrm{kcal} / \mathrm{kg}$ in every diet. The contents of $\mathrm{CP}, \mathrm{ME}$, calcium (Ca) and total phosphorous in MPD diet were fitted with the requirements calculated on the basis of BIS (Bureau of Indian Standard). Diets were formulated using locally available feedstuffs. Body weight and feed intake of the birds were recorded weekly. The results indicated that body weight and weight gain increased significantly in birds that received MPD diets in comparison with those received the other diets. Feed conversion ratio decreased significantly in all protein diets in comparison with the control. It is concluded indigenous (desi) female chicks may achieve up to $1.1 \mathrm{~kg}$ body weight at 22 weeks of age when $17 \% \mathrm{CP}$ is fed in a2700 kcal ME/kg diet.
\end{abstract}

Key words: indigenous growing chicks; Bangladesh; protein requirement; confinement

\section{Introduction}

The rural poultry generally survive on scavenging feed resource base (SFRB) like fallen grains, pulses, weeds, vegetative materials, kitchen wastes, earthworm, insects etc. The villagers traditionally supplement little or no additional feed to these birds. The country has got ample opportunity for increasing rural poultry production at small holders' level. However, its success primarily depends on the improvement of existing feeding system along with their genetic improvement.

The productivity of scavenging indigenous (desi) chickens is low but the birds are well adapted to rural condition even in adverse agro-climatic conditions (Das et al., 2008). Information in relation to protein requirements of indigenous chicken is, however limited. Scavenging feed is far from balanced and especially deficient in protein, energy and sometimes calcium for layer but high in fiber (Ukil, 1992; Biswas et al., 2005). Most of the efforts of poultry development activities in Bangladesh have taken place to improve the native stock through crossbreeding but neither the indigenous (desi) nor the cross-bed stock received adequate attention to improve their nutritional status. Limited information indicates that the productivity of desi chicken could be improved significantly if the nutrient contents of the diets are improved and if such diets are fed in 
confinement (Chowdhury et al., 2006). Therefore, the experiment reported here was undertaken to determine responses of indigenous (desi) growing chicks to least-cost diets of different protein density formulated with a few unconventional feed ingredients and to determine appropriate protein levels required in the diet to accelerate growth.

\section{Materials and Methods}

One hundred and forty four female chickens of 12 weeks old were divided into 4 dietary treatments for this study and reared on littered floor in an open sided house. The experimental house was partitioned in a way similar to experiment 1 . Four iso-caloric $(2700 \mathrm{ME} \mathrm{kcal} / \mathrm{kg}$ ) grower diets differing in protein contents were formulated for conducting the feeding trial. The diets were; conventional diet (CD): broken rice $65 \%+$ rice polish $31 \%$ + PC 1\%, low protein density (LPD): CP 15\%, moderate protein density (MPD): CP 17\% and high protein density (HPD): CP 19\%. Experimental diets are shown in Table 1. The contents of CP, ME, calcium (Ca) and total phosphorous in MPD (CP 17\%) diet were fitted with the requirements calculated on the basis of Bureau of Indian Standard (BIS).

The chemical analyses of different feed ingredients were carried out by following standard methods (AOAC, 2004; Kent et al., 1967; Hall Hacskaylo, 1963). Proximate components, calcium (Ca) and total phosphorous (P) of those ingredients were determined in the Animal Nutrition Laboratory, Department of Livestock Services (DLS) and in the Department of Poultry Science, Bangladesh Agricultural University. Calcium and total P were determined by atomic absorption and spectrophotometer, (FAO, 1989). Amino acids were determined by amino acid analyzer at the Institute of Food Science and Technology of B.C.S.I.R (Bangladesh Council for Scientific and Industrial Research) Laboratory in Dhaka. The analysis was repeated when data for any ingredient were found to be confusing.

Feed and water were supplied ad-libitum throughout the experimental period. Data on growth performance were recorded up to the point of lay. Data were analyzed statistically using analysis of variance (ANOVA) in a completely randomized design (SAS, statistical software).

\section{Results}

\subsection{Growth performance}

The effects of feeding different protein density diets on the performance of female indigenous (desi) chicks are shown in Table 2. It is evident that increasing dietary level of CP improved growth of experimental chicks. Final body weight was significantly improved in birds receiving MPD diets than the other diets $(\mathrm{P}<0.05)$ during growing period of 12-22 weeks.

Body weight gain was significantly improved in MPD than HPD and LPD diets $(\mathrm{P}<0.05)$. Feed consumption did not differ significantly in MPD, HPD and LPD diets. The birds on MPD diet consumed highest amount of feed. There was no mortality of birds in any treatment groups. Therefore, the survivability was $100 \%$ in all groups.

\subsection{Profitability analyses}

Data related to cost and return were evaluated and the results of benefit cost analysis for profit measurement of desi chicks fed on different protein density diets are shown in Table 3. Feed cost was highest in HPD diet and lowest in the CD group. Total cost of production was found highest in HPD (351.8 BDT) diet and lowest in control (315 BDT) group. Total cost of production was highest in HPD group than LPD and MPD group. Gross return/bird was highest in MPD diet and lowest in CD group. Gross return/bird increased significantly in MPD diet than LPD and HPD groups. There was no profit in any dietary groups during 12 to 22 weeks of rearing period. BCR increased significantly in MPD than LPD and HPD group $(\mathrm{P}<0.05)$, although such an increase did not permit profit. 
Table 1. Ingredients and nutrient composition of the diets of experiment.

\begin{tabular}{|c|c|c|c|c|}
\hline \multirow{2}{*}{ Ingredients (kg) } & \multicolumn{4}{|c|}{ Diets } \\
\hline & CD & LPD & MPD & HPD \\
\hline Maize & 0 & 10 & 9 & 9 \\
\hline Rice polish & 31 & 24 & 25 & 20 \\
\hline Wheat bran & 0 & 18 & 14 & 14 \\
\hline Broken rice & 65 & 33.5 & 32 & 32 \\
\hline Soybean meal & 0 & 8 & 13 & 18 \\
\hline Protein concentrate & 1 & 0 & 0 & 0 \\
\hline Mustard oil cake & 0 & 3 & 3.5 & 3.5 \\
\hline $\mathrm{DCP}$ & 2.22 & 1 & 1 & 1 \\
\hline Methonine & 0 & 0.05 & 0.05 & 0.05 \\
\hline Lysine & 0 & 0.05 & 0.05 & 0.05 \\
\hline Salt & 0.5 & 0.5 & 0.5 & 0.5 \\
\hline Lime & 0 & 1.6 & 1.6 & 1.6 \\
\hline Vitamin mineral premix & 0.25 & 0.25 & 0.25 & 0.25 \\
\hline Coccidiostat & 0.025 & 0.025 & 0.025 & 0.025 \\
\hline Total & 100 & 100 & 100 & 100 \\
\hline \multicolumn{5}{|l|}{ Nutrient composition } \\
\hline M E (kcal/ kg) & 3156 & 2704 & 2737 & 2712 \\
\hline $\mathrm{CP}(\%)$ & 11.42 & 15.33 & 17.2 & 19.1 \\
\hline $\mathrm{Ca}(\%)$ & 0.752 & 1.109 & 1.12 & 1.121 \\
\hline Total P (\%) & 0.918 & 0.707 & 0.752 & 0.719 \\
\hline Lysine (\%) & 0.437 & 0.77 & 0.903 & 1.022 \\
\hline Methonine (\%) & 0.224 & 0.538 & 0.516 & 0.539 \\
\hline ME: CP & 276.36 & 176.4 & 159.1 & 142 \\
\hline
\end{tabular}

Table 2. Performances of indigenous (desi) chicks fed on different protein density diets (12 to 22 weeks).

\begin{tabular}{llllll}
\hline \multirow{2}{*}{ Variable (g/chick) } & \multicolumn{4}{c}{ Nutrient density } & Level of \\
\cline { 2 - 6 } & CD & LPD & MPD & HPD & significance \\
\hline Initial Body weight & $565 \pm 2.51$ & $570 \pm 5.77$ & $555 \pm 2.88$ & $575 \pm 2.88$ & $\mathrm{NS}$ \\
Final body weight & $883^{\mathrm{c}} \pm 4.35$ & $1033^{\mathrm{b}} \pm 4.35$ & $1106^{\mathrm{a}} \pm 7.02$ & $1057^{\mathrm{b}} \pm 11.79$ & $*$ \\
Body weight gain & $318^{\mathrm{c}} \pm 6.80$ & $463^{\mathrm{b}} \pm .8 .50$ & $551^{\mathrm{a}} \pm 4.58$ & $482^{\mathrm{b}} \pm 9.07$ & $*$ \\
Feed Intake & $4579^{\mathrm{b}} \pm 281.88$ & $5441^{\mathrm{a}} \pm 113.65$ & $5542^{\mathrm{a}} \pm 326.74$ & $5433^{\mathrm{a}} \pm 279.31$ & $*$ \\
Survivability\% & 100 & 100 & 100 & 100 & $\mathrm{NS}$ \\
\hline
\end{tabular}

* Means bearing superscripts in a row not in common differ significantly, $* \mathrm{P}<0.05, \mathrm{NS}=$ Non significant, $\mathrm{P}>0.05$; Conventional diet (CD): broken rice $65 \%+$ rice polish $31 \%$; LPD=low protein density diet: ME $2700 \mathrm{kcal} / \mathrm{kg}+\mathrm{CP} 15 \%$; $\mathrm{MPD}=$ moderate protein density diet: ME $2700 \mathrm{kcal} / \mathrm{kg}+\mathrm{CP} 17 \%$ and $\mathrm{HPD}=\mathrm{high}$ protein density: ME $2700 \mathrm{kcal} / \mathrm{kg}+\mathrm{CP}$ $19 \%$ 
Table 3. Cost benefit analysis of desi chicks fed on different protein density diets (12 weeks to point of lay).

\begin{tabular}{|c|c|c|c|c|c|}
\hline \multirow{2}{*}{$\begin{array}{l}\text { Variables } \\
\text { (BDT/ chick) }\end{array}$} & \multicolumn{4}{|c|}{ Protein density } & \multirow{2}{*}{$\begin{array}{l}\text { Level of } \\
\text { significance }\end{array}$} \\
\hline & CD & LPD & MPD & HPD & \\
\hline Feed cost & $97.172^{b}$ & $125.56^{\mathrm{a}}$ & $131.4^{\mathrm{a}}$ & $133.65^{\mathrm{a}}$ & $*$ \\
\hline Pullet cost & 183 & 183 & 183 & 183 & NS \\
\hline Labour cost & 15 & 15 & 15 & 15 & NS \\
\hline $\begin{array}{l}\text { Medicine and } \\
\text { vaccine cost }\end{array}$ & 10 & 10 & 10 & 10 & NS \\
\hline Others cost & 10 & 10 & 10 & 10 & NS \\
\hline Total costs & $315.1^{b} \pm 5.99$ & $343.55^{\mathrm{a}} \pm 2.63$ & $349.49^{\mathrm{a}} \pm 7.74$ & $351.81^{\mathrm{a}} \pm 6.87$ & $*$ \\
\hline Gross return & $262.5^{c} \pm 1.70$ & $298.75^{b} \pm 2.13$ & $320.75^{\mathrm{a}} \pm 1.15$ & $303.5^{\mathrm{b}} \pm 2.27$ & $*$ \\
\hline Net loss/bird & $52.60^{\mathrm{a}} \pm 5.78$ & $44.80^{\mathrm{ab}} \pm 1.51$ & $28.74^{\mathrm{b}} \pm 6.80$ & $48.31^{\mathrm{a}} \pm 4.64$ & $*$ \\
\hline BCR & $0.83^{\mathrm{b}} \pm .015$ & $0.87^{\mathrm{b}} \pm .004$ & $0.92^{\mathrm{a}} \pm .02$ & $0.86^{\mathrm{b}} \pm .01$ & $*$ \\
\hline
\end{tabular}

Means bearing superscripts in a row not in common differ significantly, $* \mathrm{P}<0.05$, Conventional diet $(\mathrm{CD})$ : broken rice $65 \%+$ rice polish $31 \%+$ PC $1 \%$; LPD=low protein density: ME $2700 \mathrm{kcal} / \mathrm{kg}+\mathrm{CP} 15 \%$; MPD=moderate protein density: ME $2700 \mathrm{kcal} / \mathrm{kg}+\mathrm{CP} 17 \%$ and HPD=high protein density: ME $2700 \mathrm{kcal} / \mathrm{kg}+\mathrm{CP} 19 \%$.

\section{Discussion}

\subsection{Growth performance}

Increasing dietary level of CP improved growth of experimental chicks (Table 2). Final body weight was significantly improved in birds receiving MPD diet than those of other diets $(\mathrm{P}<0.05)$ during the growing period of 12-22 weeks. Body weight gain was highest in MPD diet $(7.87 \mathrm{~g} / \mathrm{d} / \mathrm{b})$. Kingori et al. (2003) found that indigenous grower chicks attained $11.5 \mathrm{~g} / \mathrm{d}$ body weight during 12 to 21 weeks after feeding a diet containing $16 \% \mathrm{CP}$ which was more or less close to the result of moderate nutrient density (MPD) diet containing $17 \% \mathrm{CP}$. Feed consumption and FCR was improved significantly at increasing levels of dietary protein in this study. There was no mortality of birds in any dietary groups. Chandrasiri et al. (1994) reported a very high survival rate $(92 \%)$, when village chicks were reared in a pen with free choice feeding which was very close to the result $(100 \%)$ of the present study.

\subsection{Profitability analyses}

The profitability analyses indicated that there was no profit in any dietary groups when the birds were reared from 12 weeks to the point of lay ( 22 weeks of age). This was because incomes from the bird were calculated on weight basis. Lower growth at the expense of more feed did not support their rearing for meat purpose. Rather they could be well grown and considered for future egg production, similar to high yielding modern strain. Profit may be earned with such chicks if sale price of birds could be considered on per bird basis which goes outside the scope of this study. Thus it is inferred that indigenous chicks could not be raised beyond 14 weeks of age for table purpose.

\section{Conclusions}

The results indigenous female growing chicks (12-22 weeks) of Bangladesh would require a protein density $17 \%$ in the diet to optimize feed intake and growth rate. However, this result will have to be confirmed under rural condition where supplemental feeding could be practiced in addition to scavenging, thus saving the cost of feed.

\section{Acknowledgements}

The authors are grateful to the Ministry of Education, Bangladesh for financing this project.

\section{Conflict of interest}

None to declare. 


\section{References}

AOAC, 2004. Association of Analytical Chemists, Official Methods of Analysis, 18th edition, A.O.A.C., Washington, D.C.

BIS, 1992. Bureaus of Indian Standards, New Delhi, India.

Biswas MSA, SD Chowdhury, MG Mustafa and J Bell, 2005. Availability and nutrient of scavengable feed resources and in crop and gizzard contents of scavenging ducks in Bangladesh. Proceedings of the Fourth International Poultry Show and Seminar, Organized by World's Poultry Science Association, Bangladesh Branch, Bangladesh. pp. 167-172.

Chandrasiri ADN, SP Gunaratne, SHG Wickramaratne, JA Roberts, 1994. The egg and meat production potential of village chickens under scavenging system. Proceedings of the 7th AAAP Animal Science Congress, Bali, Indonesia, II, 73-75.

Chowdhury SD, S Ahmed and MA Hamid, 2006. Improved feeding of desi chicken reared in confinement. The Bangladesh Veterinarian, 23: 29-35.

DAS SC, SD Chowdhury, MA Khatun, M Nishibori, N Isobe and Y Yoshimura, 2008. Poultry production profile and expected future projection in Bangladesh. World's Poult. Sci. J., 64: 99-117.

FAO, 1989. Production Year Book. Food and Agricultural Organization, 50, 216-219.

Hall WC and J Hackskaylo, 1963. Methods and Procedure for Plant Biochemical and Physical Research. The Exchange Store, College Station, Texas. 9-16.

Kingori AM, JK Tuitoek, HK Muiruri and AM Wachira, 2003. Protein requirements of growing indigenous chicken during the 14-21 weeks growing period. S. Afr. J. Anim. Sci., 33: 78- 82.

SAS, 2008. Statistical Analysis Systems. SAS User's Guide: Version 9.2, $2^{\text {nd }}$ edition. SAS Inst. Inc. USA.

Ukil MA, 1992. Availability of Nutrients to scavenging chickens and duck in Bangladesh. MSc thesis Poultry Science, Bangladesh Agricultural University, Mymensingh, Bangladesh. 